\title{
Prediction of the Presence of Plantaris Tendon Through Examination of Palmaris Longus Tendon. Is There a Link?
}

\author{
Predicción de la Presencia del Tendón del Músculo Plantar Mediante el \\ Examen del Tendón del Músculo Palmar Largo. ¿Hay una Relación?
}

Ozkan Kose*; Tolga Ege**; Bahtiyar Demiralp ${ }^{* * *}$; Tuba Sanal ${ }^{* * * *}$; Dogan Bek ${ }^{* * *}$ \& Mustafa Basbozkurt

KOSE, O.; EGE, T.; DEMIRALP, B.; SANAL, T.; BEK, D. \& BASBOZKURT, M. Prediction of the presence of plantaris tendon through examination of palmaris longus tendon. Is there a link? Int. J. Morphol., 32(2):589-592, 2014.

SUMMARY: The purpose of this study was to investigate the relationship between palmaris longus (PL) and plantaris (P) tendons and test the clinical usefulness of symmetry patterns between these tendons in Turkish population. This prospective study comprised a total of 240 adult patients (120 men and 120 women) who were admitted to our outpatient clinic with bilateral knee complaints that required bilateral knee MR examination during two years. Standard test (Schaefer's test, oppose the thumb to the little finger while flexing the wrist) was used to assess the presence of the PL tendon both with inspection and palpation. Knee MRI was used to determine the presence of $\mathrm{P}$ muscle belly on both sides. We have analyzed symmetric distribution pattern using Mc-Nemar test. The PL was absent unilaterally in 34 subjects (14.2\%), while it was absent bilaterally in 17 subjects (7.1\%). The P was absent unilaterally in 51 subjects $(21.3 \%)$, while it was absent bilaterally in 10 subjects $(4.2 \%)$. If PL was absent in one hand, the chance of having an ipsilateral P tendon was 70.6\%. If PL was present in one hand, the chance of having an ipsilateral P tendon was 87.6\%. The Mc-Nemar test for symmetry yielded a p value of 0.841 for ipsilateral PL and P muscles. A clear-cut link between Palmaris longus and plantaris tendons could not be demonstrated in this study. Both muscles show different variations independent from each other.

KEY WORDS: M. Palmaris longus; M. Plantaris; Tendon graft; Prevalence.

\section{INTRODUCTION}

Palmaris longus (PL) and plantaris (P) tendons are the most commonly utilized donor tendons in plastic and hand surgery due to their sufficient diameter, length, accessibility and low donor site morbidity (Wehbé, 1992). Furthermore, harvesting these tendons is considered to have no effect on residual limb functions (Sebastin et al., 2005a). Both muscles are accepted as phylogenetically retrogressive muscles which exhibit distinct structural variations, however entire absence of PL and P tendons is relatively common variations in general population. Several studies have documented the prevalence of absence of these tendons in different ethnic populations (Aragao et al., 2010; Kose et al., 2009; Sebastin et al., 2005b; Herzog, 2011; Thompson et al., 2001).

When PL tendon is planned to be harvested, it can be easily detected with a simple physical examination test due to its subcutaneous placement (Mishra, 2001). In case of bilateral absence of PL or insufficiency of the harvested PL tendon during the surgery, surgeons may need to harvest $\mathrm{P}$ tendon as an alternative. On the other hand, there is no physical examination test to detect whether $\mathrm{P}$ tendon is present or not. It is advisable to confirm the presence of $\mathrm{P}$ tendon to avoid unnecessary dissections. This can be achieved with either ultrasound or magnetic resonance imaging (Mackay \& McCulloch, 1990; Saxena \& Bareither, 2000).

However, radiological evaluation may not be readily available in certain circumstances, moreover it is time consuming and increases the total cost of the treatment. PL and $\mathrm{P}$ muscles are considered homologous muscles of the upper and lower extremity (George, 1953). Therefore, these tendons may be simultaneously present or absent. This

\footnotetext{
* Antalya Education and Research Hospital, Orthopedics and Traumatology Department, Antalya, Turkey.

** Gulhane Military Medical Academy, Orthopedics and Traumatology Department, Ankara, Turkey.

*** Medipol University Medical Faculty, Orthopedics and Traumatology Department, Istanbul, Turkey.

*****Gulhane Military Medical Faculty, Radiology Department, Ankara, Turkey.
} 
hypothesis was tested previously in few numbers of studies in different ethnic groups (George; Harvey et al., 1983; Vanderhooft, 1996; Moss, 1988; Venter et al., 2009). However, the prevalence of absence of these tendons shows great variations among populations. The purpose of this study is to investigate the relationship between $\mathrm{PL}$ and $\mathrm{P}$ tendons and test the clinical usefulness of symmetry patterns between these tendons in Turkish population.

\section{MATERIAL AND METHOD}

This prospective study comprised a total of 240 adult patients (120 men and 120 women) who were admitted to our outpatient clinic with bilateral knee complaints that required bilateral knee MR examination between August 2011 and August 2013. This study was carried out according to the Declaration of Helsinki and Institutional Review Board approved the study protocol and all patients gave informed consent prior to inclusion.

At initial admission all patients were examined to assess the presence of the PL tendons. Subjects with a history of injury, past surgical procedure, disease or abnormality of the upper and lower limbs which would preclude examination for the presence of the P and PL tendons were excluded from the study. Standard test (Schaefer's test, oppose the thumb to the little finger while flexing the wrist) was used to assess the presence of the PL tendon both with inspection and palpation (Schaefer, 1909). If the tendon was not visualized or palpable, an additional test (Mishra's second test, abduct the thumb against resistance with the wrist in slight flexion) was used to confirm the absence (Mishra). If both tests were negative, it was considered absent (Fig. 1).

Knee MRI was used to determine the presence of $\mathrm{P}$ tendon on both sides. P tendon was accepted as present when the P muscle belly was detected to have a separate fascial sheath deep to the lateral head of gastrocnemius on T1-weighted axial MRI sections. If the muscle belly cannot be detected on serial sections, it was considered absent (Fig. 2). The presence of P tendon was evaluated and recorded by two independent radiologists who were specialist on musculoskeletal radiology at separate times and any discrepancy was subsequently resolved by consensus.

Finally, we have collected the data about the existence of PL through physical examination and P through MRI examination in the same subject. Data on patient age and sex were recorded from hospital records. Continuous variables were stated as mean and standard deviation and categorical variables as percentage and frequency distribution. We have analyzed symmetric distribution pattern using Mc-Nemar test. A p value less than 0.05 was set as significant.

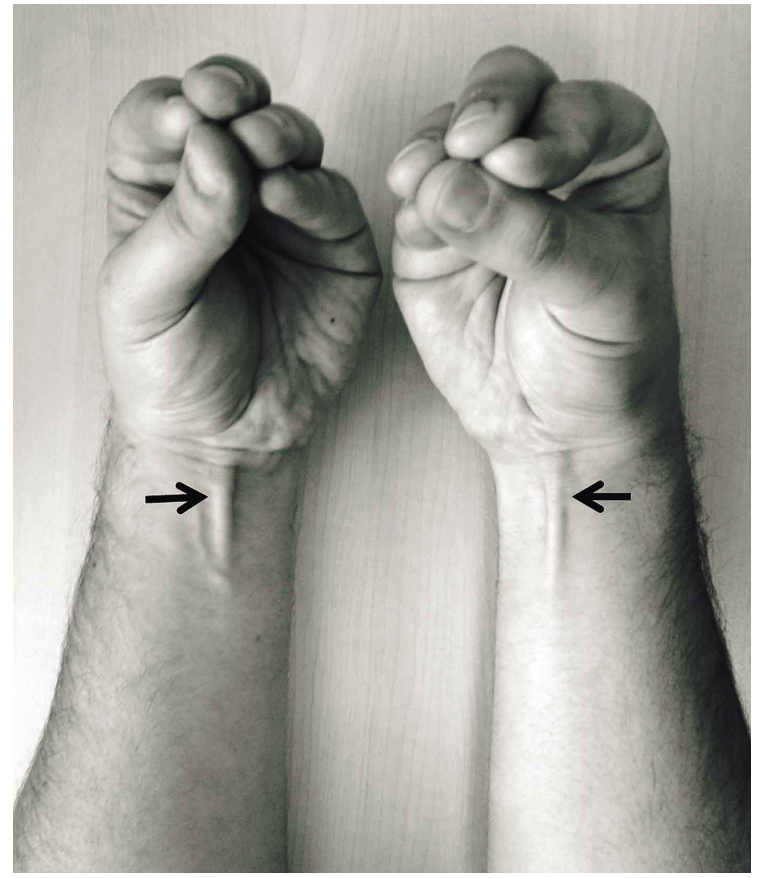

Fig. 1. Photograph of a 32-year-old male patient who has bilateral Palmaris longus tendons (black arrows).

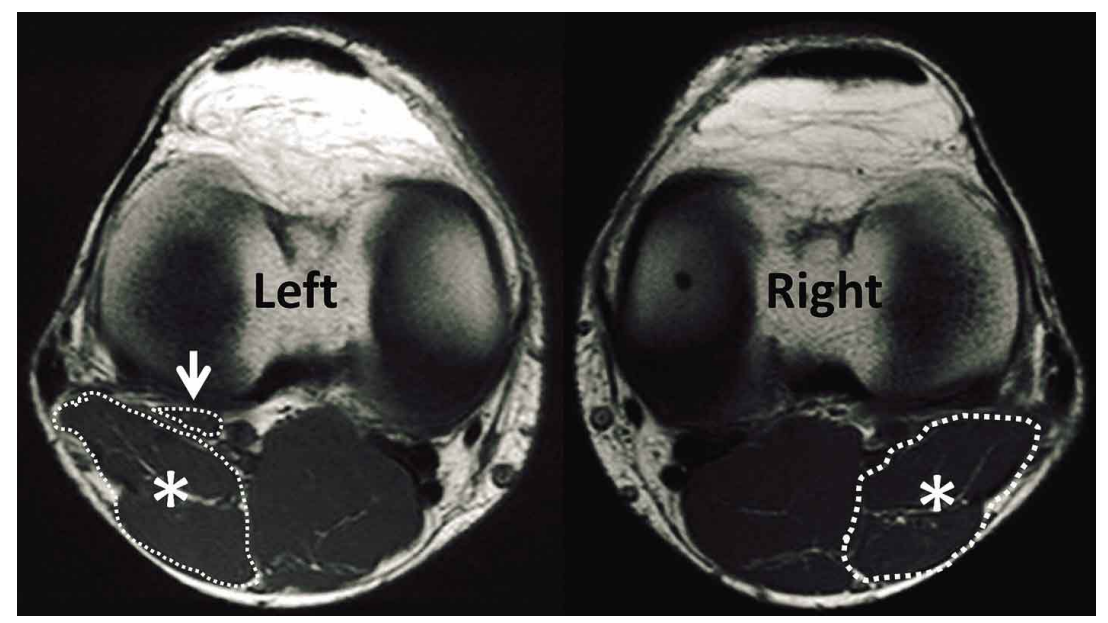

Fig. 2. T1 weighted axial MR images of both knees of the same subject. White asterix show the lateral head of gastrocnemius on both sides. While plantaris muscle belly is not observed on the right side, it is well delineated with a separate fascial sheath on the left side (white arrow). 


\section{RESULTS}

We analyzed 240 patients (120 men and 120 women) with a mean age of $37.5 \pm 12.3$ (range, 17-66). The PL tendon was absent unilaterally in 34 subjects (14.2\%), while it was absent bilaterally in 17 subjects $(7.1 \%)$. The remaining 189 subjects $(78.8 \%)$ had both PL tendons. The P tendon was absent unilaterally in 51 subjects (21.3\%), while it was absent bilaterally in 10 subjects $(4.2 \%)$, and in remaining 179 subjects $(74.6 \%)$ both $\mathrm{P}$ tendons were present. Among all subjects, there were only 2 subjects $(0.8 \%)$ who lacked both $\mathrm{PL}$ and $\mathrm{P}$ tendons. If $\mathrm{PL}$ was absent in one hand, the chance of having an ipsilateral P tendon was $70.6 \%$. If PL was present in one hand, the chance of having an ipsilateral $\mathrm{P}$ tendon was $87.6 \%$. The accuracy of assumption of symmetric presence and absence of both tendons on ipsilateral extremities was $79.3 \%$. Cross-tabulation of PL and P tendons in ipsilateral extremities is presented in Table I. The McNemar test for symmetry yielded a $\mathrm{p}$ value of 0.841 for ipsilateral PL and P muscles.

Table I. Cross tabulation of PL and P tendons in ipsilateral members.

\begin{tabular}{|c|c|c|c|c|c|}
\hline & & & M. & taris & Totol \\
\hline & & & Absent & Present & Iotal \\
\hline & & Number of subjects & 20 & 48 & 68 \\
\hline & A hsent & Percent within PL & $29.4 \%$ & $70.6 \%$ & $100.0 \%$ \\
\hline & Absent & Percent within $\mathrm{P}$ & $28.2 \%$ & $11.7 \%$ & $14.2 \%$ \\
\hline M. palmaris & & Percent of Total & $4.2 \%$ & $10.0 \%$ & $14.2 \%$ \\
\hline longus & & Number of subjects & 51 & 361 & 412 \\
\hline & Present & Percent within PL & $12.4 \%$ & $87.6 \%$ & $100.0 \%$ \\
\hline & Present & Percent within $\mathrm{P}$ & $71.8 \%$ & $88.3 \%$ & $85.8 \%$ \\
\hline & & Percent of Total & $10.6 \%$ & $75.2 \%$ & $85.8 \%$ \\
\hline & & Number of subjects & 71 & 409 & 480 \\
\hline$T$ & & Percent within PL & $14.8 \%$ & $85.2 \%$ & $100.0 \%$ \\
\hline 1 otal & & Percent within $\mathrm{P}$ & $100.0 \%$ & $100.0 \%$ & $100.0 \%$ \\
\hline & & Percent of Total & $14.8 \%$ & $85.2 \%$ & $100.0 \%$ \\
\hline
\end{tabular}

Table II. Previously published anatomic studies that reported the relationship between PL and P tendons in relevant literature.

\begin{tabular}{lccccc}
\hline \multirow{2}{*}{ Author } & Year & $\begin{array}{c}\text { Number of } \\
\text { matched limbs }\end{array}$ & \multicolumn{2}{c}{$\begin{array}{c}\text { The overall prevalence of absence } \\
\text { (unilateral or bilateral) }\end{array}$} & $\begin{array}{c}\text { Symmetric } \\
\text { pattern }\end{array}$ \\
\cline { 4 - 5 } & & 552 & M. palmaris longus & M. plantaris & \\
\hline George & 1953 & 1316 & $21.7 \%$ & $7.6 \%$ & None \\
Harvey et al. & 1983 & 300 & $20.9 \%$ & $18.2 \%$ & None \\
Moss & 1988 & 372 & $11.6 \%$ & $5 \%$ & None \\
Venderthooft & 1996 & 302 & $10.8 \%$ & $4.8 \%$ & None \\
Venter et al. & 2009 & 480 & $14.2 \%$ & 11.5 & None \\
Current study & 2013 & & $21.2 \%$ & $25.4 \%$ & None \\
\hline
\end{tabular}
of 276 cadavers to investigate the coincidence of these muscles and could not demonstrate an association between the occurrence of PL and P muscles (George). Harvey et al., dissected 658 cadavers to identify the relationship between PL and P tendons. Similarly, they found no significant relationship between these tendons. Later on, three other investigators Moss, Venderthooft and Venter et al., had also tested this hypothesis, but all these studies failed to show any evidence that PL and $\mathrm{P}$ has a symmetric co-existence (Vanderhooft; Moss; Venter et al.). Our findings are consistent with all these previous studies, and there seems no relationship between these tendons. 
There are some strengths and limitations of this study. Present study only provides information about the absence or presence of these tendons but not about their quality regarding length and width. However, not only their presence but also their sufficiency to be used as a tendon graft is crucially important (Jakubietz et al., 2011). The P tendon was detected with the use of knee MR images which is not totally a reliable method. However, two radiologists evaluated all knee images in order to decrease the rate of misinterpretation. Furthermore, absence of PL tendon was evaluated by the same investigator and a second test was performed in case of suspicion.

In conclusion, the presence or the absence of $\mathrm{P}$ muscle cannot be predicted through examination of PL muscle. Each muscle presents variations independent from each other.

KOSE, O.; EGE, T.; DEMIRALP, B.; SANAL, T.; BEK, D. \& BASBOZKURT, M.Predicción de la Presencia del tendón del músculo plantar mediante el examen del tendón del músculo palmar largo. ¿Hay una relación? Int. J. Morphol., 32(2):589-592, 2014.

RESUMEN: El propósito de este estudio fue investigar la relación entre los tendones del músculo palmar largo (MPL) y músculo plantar (MP) y poner a prueba la utilidad clínica de los patrones de simetría entre estos tendones de la población turca. Estudio prospectivo realizado sobre 240 pacientes adultos ( 120 hombres y 120 mujeres) que ingresaron en la clínica por síntomas de dolor en la rodilla bilateralmente, quienes requerían un examen de RM de rodilla durante dos años. Se utilizó la prueba estándar (prueba de Schaefer, se oponen el pulgar hasta el dedo mínimo, mientras se flexiona la muñeca) para evaluar la presencia del tendón MPL tanto con la inspección y palpación. La RM de la rodilla se utilizó para determinar la presencia de vientre muscular plantar en ambos lados. Se analizó el patrón de distribución simétrica mediante la prueba de McNemar. El tendón del MPL estuvo ausente de manera unilateral en 34 pacientes $(14,2 \%)$ y bilateralmente en 17 pacientes $(7,1 \%)$. El tendón del MP estuvo ausente de manera unilateral en 51 pacientes ( $21,3 \%$ ) mientras que bilateralmente no estaba en 10 pacientes $(4,2 \%)$. Si el tendón del MPL estuvo ausente en un lado, la probabilidad de tener un tendón del MP ipsilateral fue del 70,6 \%. Si el tendón del MPL estaba presente en un lado, la probabilidad de tener un tendón del MP ipsilateral fue 87,6\%. La prueba de McNemar - simetría produjo un valor p de 0,841 para los músculos PL y P ipsilaterales. Una relación directa claro entre los tendones de los músculos PL y P no se pudo demostrar en este estudio. Ambos músculos muestran diferentes variaciones independiente uno del otro.

\section{PALABRAS CLAVE: M. Palmar largo; M. Plantar; Injerto de tendón; Prevalencia.}

\section{REFERENCES}

Aragao, J. A.; Reis, F. P.; Guerra, D. R. \& Cabral, R. H. The occurrence of the plantaris muscle and its muscle-tendon relationship in adult human cadavers. Int. J. Morphol., 28(1):255-8, 2010.

George, R. Co-incidence of palmaris longus and plantaris muscles. Anat. Rec., 116(4):521-3, 1953.

Harvey, F. J.; Chu, G. \& Harvey, P. M. Surgical availability of the plantaris tendon. J. Hand Surg. Am., 8(3):243-7, 1983.

Herzog, R. J. Accessory plantaris muscle: anatomy and prevalence. HSS J., 7(1):52-6, 2011.

Jakubietz, M. G.; Jakubietz, D. F.; Gruenert, J. G.; Zahn, R.; Meffert, R. H. \& Jakubietz, R. G. Adequacy of palmaris longus and plantaris tendons for tendon grafting. J. Hand Surg. Am., 36(4):695-8, 2011.

Kose, O.; Adanir, O.; Cirpar, M.; Kurklu, M. \& Komurcu, M. The prevalence of absence of the palmaris longus: a study in Turkish population. Arch. Orthop. Trauma Surg., 129(5):609-11, 2009.

Mackay, I. R. \& McCulloch, A. S. Imaging the plantaris tendon with ultrasound. Br. J. Plast. Surg., 43(6):689-91, 1990.

Mishra, S. Alternative tests in demonstrating the presence of palmaris longus. Indian J. Plast. Surg., 34(1):12-4, 2001.

Moss, A. L. H. Is there an association between an absence of palmaris longus tendon and an absence of plantaris tendon? Eur. J. Plast. Surg., 11(1):32-4, 1988.

Saxena, A. \& Bareither, D. Magnetic resonance and cadaveric findings of the incidence of plantaris tendon. Foot Ankle Int., 21(7):570-2, 2000.
Sebastin, S. J.; Lim, A. Y.; Bee, W. H.; Wong, T. C. \& Methil, B. V. Does the absence of the palmaris longus affect grip and pinch strength? $J$. Hand Surg. Br., 30(4):406-8, 2005a.

Sebastin, S. J.; Puhaindran, M. E.; Lim, A. Y.; Lim, I. J. \& Bee, W. H. The prevalence of absence of the palmaris longus--a study in a Chinese population and a review of the literature. J. Hand Surg. Br., 30(5):525$7,2005 b$

Schaeffer, J. P. On the variations of the palmaris longus muscle. Anat. Rec. 3(4):275-8, 1909.

Thompson, N. W.; Mockford, B. J. \& Cran, G. W. Absence of the palmaris longus muscle: a population study. Ulster Med. J., 70(1):22-4, 2001.

Vanderhooft, E. The frequency of and relationship between the palmaris longus and plantaris tendons. Am. J. Orthop. (Belle Mead N. J.), 25(1):38-41, 1996

Venter, G.; Albert-Neels, V. S. \& Bosman, M. C. A comparison of the palmaris longus and plantaris muscles employed as flaps in reconstructive surgery, 2009. Available in: http://repository.up.ac.za/ bitstream/handle/2263/12320/venter_relationship_poster. pdf?sequence $=1$

Wehbé, M. A. Tendon graft donor sites. J. Hand Surg. Am., 17(6):1130-2, 1992.

\section{Correspondence to:}

Dr. Ozkan Kose

Kultur mah. 3805. sk Durukent Sitesi

F Blok Daire 4, Kepez, Antalya

TURKEY

Received: 03-12-2013

Accepted: 03-03-2014

Email: drozkankose@hotmail.com 